\title{
The National Library of Romania in the Service of Communities: a Qualitative Analysis to Identify the Needs of the Users in the Free Reading Spaces
}

\author{
Mădălina Lefter \\ Librarian, National Library of Romania \\ PhDc, University of Bucharest \\ E-mail madalina.lefter@gmail.com
}

The article is based on the dissertation Biblioteca Națională a României în slujba comunităților: o analiză calitativă pentru identificarea nevoilor utilizatorilor spațiilor libere pentru lectură [The National Library of Romania in the service of communities: a qualitative analysis to identify the needs of the users in the free reading spaces], held in June this year, at the final stage of the Master Program Management of Information in Contemporary Society. The research took place in 15th-26th of April, 2019. Our approach is unique, as the official activity reports published by the National Library are lacking the qualitative studies which would have helped establishing the directions of development of the services dedicated to different types of users. The quantitative reports officially reveal that the users tend to favor the free reading spaces in spite of the reading rooms. These statistics lead us to the idea that the library must operate changes in its public policies, considering new services and healthy conditions for 54,000 free spaces users per year. Who are these people? Where are they coming from? What do they need? What caused the change in their preferences? What does the National Library offer in these spaces to help people and what must it continue to do, to maintain its active place in the knowledge society and a determined role in the Romanian culture? The aim of our work is to answer these questions, or at least to approximate them.

Keywords: National Library of Romania; library spaces; free reading spaces; Romanian

\section{The National Library of Romania and its environment: competitors and users: an introduction}

The National Library of Romania (NLR), depository of the mobile national cultural heritage, is at present the largest informational institution of the country. Over 12 million bibliographic units make up the patrimony of the written memory of the Romanian nation, part of a precious legacy with Western European but also Byzantine influence. Any scientific approach at this level requires maximum and responsible attention. Major decisions must take into account not the emotional patriotic feeling, but the awareness of the strategic place that an institution of such magnitude must occupy in the Romanian culture, as one of the most valuable intellectual resources of our country.

In the post-revolutionary democracy (after 1989), Romania has not conceived a solid strategy to develop the public libraries, as the Communists had done, of course, to ensure their doctrinal strengthening and dissemination. Unlike them, today's leaders of culture and education have given libraries the freedom to complete their collections by themselves, the only impediment being the always austere budgets. Let us not forget that the most important investment in the technology of these institutions, The Biblionet Program, was possible through Bill \& Melinda Gates Foundation and not with public funds. The lack of interest for reading is mainly felt in these institutions and it has already visible consequences in the Romanian education, despite the legislative changes applied to the education system in recent years. Romania, in the knowledge society, registers 42 percent functional illiteracy, among 15-year-olds (Peticilă 2018), given that, unlike the nineteenth and twentieth centuries, we have editorial productions comparable to the Western countries, as

Revista Română de Biblioteconomie şi Ştiința Informării = Romanian Journal of Library and Information Science ISSN 2559-5490, ISSN-L 1841-1940 • Volume 15 Issue 3-4 2019 pp. 75-89 https://doi.org/10.26660/rrbsi.2019.15.34.75

This work is licensed under a Creative Commons Attribution-NonCommercial-NoDerivatives 4.0 International License 
The National Library of Romania in the Service of Communities: a Qualitative Analysis to Identify the Needs of the Users in the Free Reading Spaces

nothing hinders the publication of any kind of information. We no longer have censorship institutions, and the information is one click away.

The Internet is a major competitor of the library, when it comes to the general public. As a tool of knowledge, the Internet becomes the main source of information available to anyone, regardless of space and time. Anyone can find out about editorial news, theatrical performances, new movies, everybody is able see how a work is received by critics more or less consecrated. It becomes obvious that not much information is missing. Its quality, on the other hand, is missing.

However, the NLR has never carried out a study on national reading habits, in order to come up with solutions to the problems of education. No government seemed interested in a national interdisciplinary research program of the fundamental needs in culture: who reads, what people prefer to read, where do they read, do they have a proficient level of reading comprehension? The truth is we know nothing about these things. At the same time, we must take into account that reading/education influences the economic life of the individual, in an indirect but decisively way. Personal development, adaptation to the environment and prosperity are consequences of knowledge, acquisition and understanding of the information applicable in everyday life.

If we look, for example, at the book market statistics, at the sales of large bookstores and publishers during book fairs, we might mistakenly believe that things are going well. "The Romanians return to reading. The book market reaches the maximum of the last 7 years", headlines the online edition of a central daily newspaper (Cicovschi 2018). But statistics refer to trade. It does not exactly refer to who buys and why. Experience shows that there are people who buy books without reading them, as others read without necessarily buying them, either downloading them from the internet or borrowing them from the library. One can even read them in a large bookstore, if a special offer or simply a proper space gives people this chance.

It is important to recognize that nowadays big bookstores are huge competitors for the libraries. They can provide quick access to editorial news, which libraries do not always succeed due to the document processing activities, which require time and human resources. The bookstores have diversified their offer. They are not only selling books, but they also provide other products: from household items to show tickets. They organize cultural events and they offer comfortable reading spaces.

The information reported by publishers and bookstores can also give us hints about what buyers prefer (though they can be readers or not). Data about the readers' preferences are often found out from the public and school libraries reports. the NLR, for instance, is able to register the preferences of its patrons only when they use the reading rooms and the Reference Service or when other public libraries access the International Interlibrary Loan Service. Other public libraries, such as the county or communal ones, make reports on the needs of their readers as they check the previous home loan requests, in order to establish their resources acquisition policy. For example, in 2015, the County Library "Duiliu Zamfirescu" Vrancea purchased especially chick lit and fantasy belletristic genres. But these are in-house studies meant to serve the reading interests of the local community. We do not see them in qualitative reports at national level, which would help developing successful strategies regarding education.

The annual reports on culture consumption elaborated by the National Institute of Statistics (NIS) remain in the quantitative area. From the last study on the activity of the cultural units, published in 2018 and referring to the year 2017, which includes libraries, the figures describe an alarming picture. Thus, we find out that at national level, the number of volumes in collections decreased by $0.7 \%$, and that purchases fell by 5.3\%, compared to 2016 (Institutul Naţional de Statistică 2017). But if these figures can reflect the budgetary decline and not the reading habits, be so. However, the fact that from 2016 to 2017 the number of active users decreased by 5.4\%, according to the same study shows clearly that in the spaces intended for reading and around them people read less. We can also formulate an idea about where and how much people reads, considering that in 2017, according to NIS, the subscriber of a library in Romania used, on average, 11 volumes, with a maximum registered by the university libraries, which have provided 18 bibliographic units to a user, with a minimum of 8 units in school libraries (Institutul Naţional de Statistică 2017). The 
The National Library of Romania in the Service of Communities:

a Qualitative Analysis to Identify the Needs of the Users in the Free Reading Spaces

communal ones boast an additional volume at the average value of consumption per user, with 9 units, according to NIS.

The weaknesses of education are also reflected in public discourse. Narrowing of understanding, acceptance of others, tolerance, at the level of identifiable groups in social media networks, the progressive inflection of everything that is national, including identity, describes societal failures that we do not know yet to manage and whose outlook is difficult to anticipate. In developing its management policies, the National Library must take into account these realities, for beyond its heritage mission, par excellence, it has also the obligation to place its country under the shelter of knowledge.

\section{Free reading spaces in the National Library of Romania}

The National Library of Romania has arranged in its new headquarters a series of spaces dedicated to reading, individual or group study, but also to socialization. They are organized around the Atrium, on the ground floor and they bear the names of the Greek letters Alfa ("Alpha"), Beta, Delta, Gamma, Epsilon, Theta, Sigma and Omega, to which are added Papirus ("Papyrus"), Pergament ("Parchment") and Scriptorium, names with deep resonances in the history of writing. The latter are also exhibition spaces. The six from mezzanine received the names of some symbolic spaces in Romanian culture: Dealul Spirii, Podu Vechi, Izvoru Rece, Fântâna Zodiac, Podul Mihai Voda, Strada Mântuleasa. And here are organized exhibitions of photography, fine arts, reproductions of documents in the special collections of the library, in various thematic series. The upper floors no longer have such areas, but the large flow of users in recent years has determined the library to arrange on the first and second floors such spaces, arranged in a circular fashion, infused by the natural light coming splendidly through the dome glass of the building.

The designation of free reading spaces is related to the way people use them. Moreover, their initial toponymy did not come into the public's consciousness, because the names are not displayed anywhere other than in the Library Guide on the library's website (Biblioteca Națională a României s.a.). Users call them simply free spaces, a phrase used even by library staff in current speech and internal documents. Staying in these spaces does not depend on the use of the library's documentary resources and is not conditional on leaving personal belongings at the wardrobe. The users come with their luggage, they benefit of tables equipped with unidirectional lamps, identical to those in the reading rooms, they can buy coffee, sandwiches, non-alcoholic beverages from the vending machines at the ground floor. Occupation of the seats is made on a first-come basis. No sign prohibits the use of mobile phones, but on the contrary, they can connect wirelessly to the Internet, without a time limit, for free, without restrictions regarding the sound volume when using their gadgets. In fact, there is no regulation that strictly concerns these spaces, but a general one, dedicated to all library patrons, which specifies rules regarding the access to collections and the use of reading rooms.

According to the Regulation, the access to the NLR takes place on the basis of an individual library card, not transferable. This is obtained without difficulty, by presenting an ID card and completing a form. The library card is issued on the spot, free of charge. If a user does not have the card and wishes to enter the library, a temporary license can be provided. Only in case of loss and request of a duplicate, the library charges a $15 \mathrm{RON}$ fee.

In the open spaces there are work facilities, with tables for 2, 4, and 8 persons, equipped with lamps and chairs. Included in these spaces, the socializing areas on the ground floor and mezzanine are furnished with slightly shorter dining sets and armchairs, but the experience shows that they are also used for study.

The open spaces are available to public every day, from Monday to Friday, starting at $8 \mathrm{am}$. On Tuesdays and Thursdays, they are open until $8 \mathrm{pm}$, and the rest of the days until $6 \mathrm{pm}$. During the exam sessions, the library opens then spaces from the ground floor and from mezzanine on Saturdays and Sundays, between 9 am to $5 \mathrm{pm}$.

Because it was conceived as an open space, offering both a quiet place, for those in need of study, 
The National Library of Romania in the Service of Communities:

a Qualitative Analysis to Identify the Needs of the Users in the Free Reading Spaces

as well as artistic manifestations, cultural programs dedicated to the entire community, the Atrium becomes the place where everyone's needs have to be fulfilled. Apart from artistic events (exhibitions, reading halls, musical sessions) the library rents out spaces for various other cultural events, such as product launches, national and international conferences, congresses with hundreds, sometimes thousands of participants. Thus, during these events, the free reading spaces around the Atrium become transit zones.

Each year, the Institutional Development Service of the National Library of Romania analyzes the degree of occupancy of these spaces to see to what extent the library must open the upper floors to the public and to adjust the program according to the needs of the public and the human resources of the library. They are internal, unpublished materials, most often serving administrative matters, without relevance to the public, for example, in scheduling the cleaning program or the area distribution of employees in the Department of Protection and Guard.

348 seats are available in the spaces for free readings; however, frequented all year round are those from the ground floor and from mezzanine. During exam sessions, the library must also open the 1 st and 2nd floors. Because the library does not yet have an RFID check-in and check-out system, employees are required to physically count the people at the desks. If during the usual periods of the year, such as October, November, December, March, April, this is possible, difficult, but achievable, because there are few users, during exam sessions, a naked eye counting becomes impossible.

These counts are carried out at $1 \mathrm{pm}$ and $5 \mathrm{pm}$, temporal sections proven by the experience of the last years as peaks of the presence of users in the spaces for free readings. The librarians of the Department of Institutional Development have found that on Tuesdays and Thursdays, when the closing time is $8 \mathrm{pm}$, the most intense traffic is registered at $5 \mathrm{pm}$. When the library closes at $6 \mathrm{pm}$ (Mondays, Wednesdays and Fridays), the peak time is $1 \mathrm{pm}$. As it is shown in Table 1 [1], the following average occupancy rates, related to the total number of 348 seats, were obtained for the period October 1-31, 2018:

Table 1. Occupation rate of the free reading spaces (1.11.2018-31.11.2018)

\begin{tabular}{|l|c|c|}
\hline Hour & $\mathbf{1} \mathbf{~ p m}$ & $\mathbf{5} \mathbf{~ p m}$ \\
\hline Daily average of users & 176 & 147 \\
\hline Occupation rate (\%) & 45.83 & 38.28 \\
\hline
\end{tabular}

The official estimates are indicated in the annual activity reports of the library, and the one regarding the year 2018, published in 2019, shows that the spaces for free readings were used by 54 thousand readers, with a daily average of 183 people. The report mentions that "the value of this average is obtained from the total users of free spaces, divided by the number of days when the library was opened that is to 295" (Biblioteca Națională a României 2018a).

\section{A qualitative study: objectives, research method and materials, the results and their interpretation}

\subsection{Objectives}

The difference between the total number of users of the reading rooms, of 21 thousand people, calculated during 2018 and the ones counted on the free reading spaces, 54 thousand, reflects the public's clear preference for the areas not covered by the Regulation (Biblioteca Națională a României 2018b) and, more importantly, an interest of at least twice smaller for the library's collections. Moreover, if we look at the previous Activity Report, we will see that in 2017, the number of users of these spaces was 41,500. Up to 54 thousand registered in 2018 means an increase of 12500 people. A $30 \%$ increase in traffic indicates a significant population growth. It is clear that we must be interested in what brought all these people here, in such a short time, what 
The National Library of Romania in the Service of Communities: a Qualitative Analysis to Identify the Needs of the Users in the Free Reading Spaces
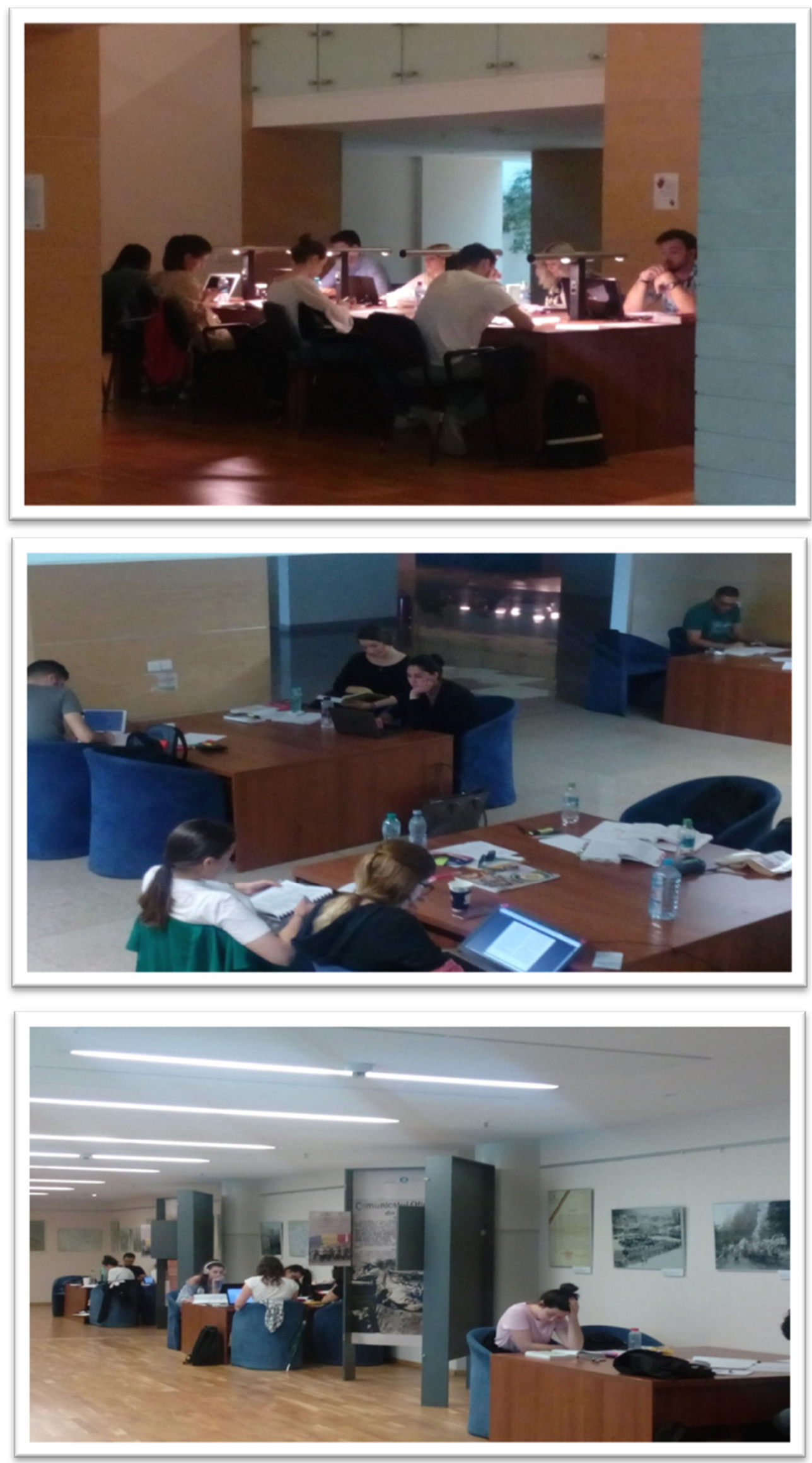

Photos taken in the spaces for free readings of the National Library of Romania during the summer exam session, 2019 
The National Library of Romania in the Service of Communities: a Qualitative Analysis to Identify the Needs of the Users in the Free Reading Spaces

their needs are, to keep them in the spaces of the National Library of Romania, what can we do for them.

Then, vital for the library will be the design / improvement of some services dedicated to the users, as well as the elaboration of projects that bring these people closer to the collections. In order to have a say in education, the ultimate challenge of the library must be to connect Millennial generation to its collections and guide them in finding and using valid information resources in the digital world.

Our research aimed to discover what professional environments users are coming from, what ages they have, what is the purpose of their presence in the free reading spaces, which is the level of satisfaction / dissatisfaction regarding the ergonomic elements: temperature, light, furniture, noise level and the Internet connection, considering that it has become a fundamental facility in the knowledge society.

An immediate objective is also to establish an access program in these spaces, which responds to the needs of the users, but which can be supported by the human resources of the library, the insufficient staff of the institution being known as a major problem.

We are also interested in how users appreciate the access to the free reading spaces and if an electronic identifying system would be necessary. We also try to find out if the users have complained regarding the level of civility, considering the lack of technical means of monitoring and control and the insufficient human resources. Their opinions are important to us in order to know precisely what is lacking, what is to be fixed, what is not working, what we should readjust. That is why, in our research, we paid special attention to the things that they would change in these spaces and how they would do it.

Last but not least, thanks to a challenge recently launched in the library world by the Department of Communication Sciences within the Faculty of Letters of the University of Bucharest, we are also interested in the ability of the public library, in general, to create happiness. The topic was debated at the International Conference entitled Fericirile; Căile lor... [Happiness; Its ways...] held in November, 2018. However, we consider that such a generous topic was far from being exhausted and the opinion of our patrons can reveal new and interesting ideas on this subject matter.

\subsection{Research method and materials}

In order to have a realistic picture of our users 'needs, we considered that an efficient qualitative method was the direct observation of the users' behavior and the questioning of a consistent segment of the public, with the help of an opinion questionnaire. Since a demonstration using the total number of subjects, 54,000, would have far exceeded our physical capabilities, we considered that reporting to the daily average of users would bring us closer to at least one side of the truth, if not to a final, exhaustive picture. Therefore, we considered that 210 queries represent significantly more than the daily average of 183 persons, calculated by our colleagues, for 2018 .

We have chosen a period of intense traffic in these spaces, namely the pre-exam and exam session periods: 16 to 26 May, 2019, during which the first and second floors of the library were open.

The questionnaire, designed in six points, in multiple choice format, had a version in Romanian and one in English, because the National Library of Romania is open to everybody, regardless of nationality, ethnic identity, religion, sex, politic affiliation, etc. In evaluating the results, we made no distinction between Romanians and those of different nationalities.

Each objective of the research, mentioned above, corresponded to a challenge from the questionnaire. Many users annotated their answers outside the box, expressing their own views. As it will be observed in the following, most of them have offered us suggestions for various changes and this was the first good news for our research. Our readers have opinions about the library and they need it, they have expectations from it. 
The National Library of Romania in the Service of Communities: a Qualitative Analysis to Identify the Needs of the Users in the Free Reading Spaces

\subsection{The results of the study and their interpretation}

Out of 210 questionnaires, 203 returned to us with answers, which allowed us to remark that they were open to communicate. The first finding was related to their age. Our respondents are between 16 and 62 years old.

The occupational areas where they come form is diverse, the majority being an active population, as soon as only 4 persons declared that they are retired. The students are dominant, which means that the National Library of Romania breaks an important segment of public from the university libraries, where, in all likelihood, they do not have enough space. We included in this group Masters and $\mathrm{PhD}$ students, as well as the subjects coming from the school environment.

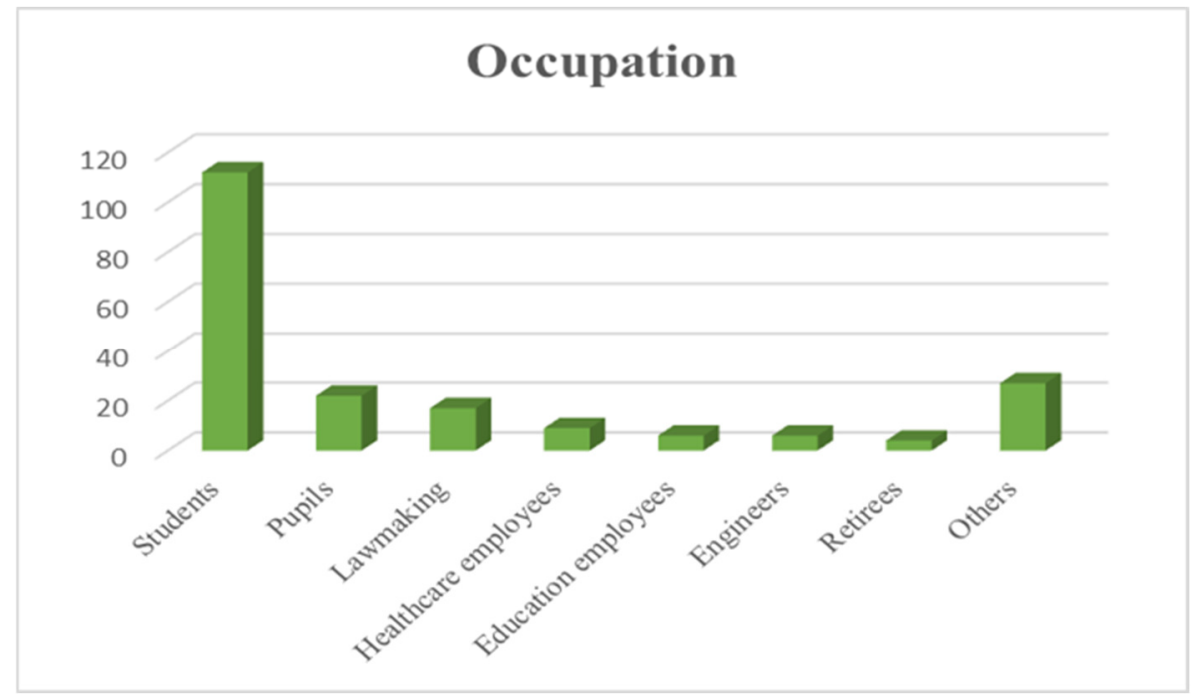

Figure 1. The occupational domains of the users of the free reading spaces in the NLR

The following table highlights more clearly the professional areas our users come from and in which proportions:

Table 2. Occupational domains of users of free reading spaces

\begin{tabular}{|l|c|c|}
\hline Students & 112 & $55 \%$ \\
\hline Pupils & 22 & $11 \%$ \\
\hline Legal professions & 17 & $8 \%$ \\
\hline Care assistants & 9 & $4 \%$ \\
\hline Teachers & 6 & $3 \%$ \\
\hline Engineers & 6 & $3 \%$ \\
\hline Other professions & 27 & $13 \%$ \\
\hline Retirees Total & 4 & $2 \%$ \\
\hline \multicolumn{2}{|c|}{203} & $100 \%$ \\
\hline
\end{tabular}

If the youngest respondents are 16 years old, it means that the $22 \%$ of the table above are high school students. The closure of many school libraries in Romania in recent years is a well-known situation. The fact that they come to learn at the National Library shows that they are looking for free reading spaces now.

The proximity of the Bucharest Law Court probably justifies the presence of many users, $8 \%$ coming from the legal environment (lawyers, judges, legal advisers).

In the section "other professions" we have classified the domains represented by less than 4 subjects: economists, DJs, IT people, biologists, freelancers, but also those who refused to declare their occupation.

The answers for "What type of activity do you prefer in the free spaces of the National Library of Romania?" let us know their immediate needs: 


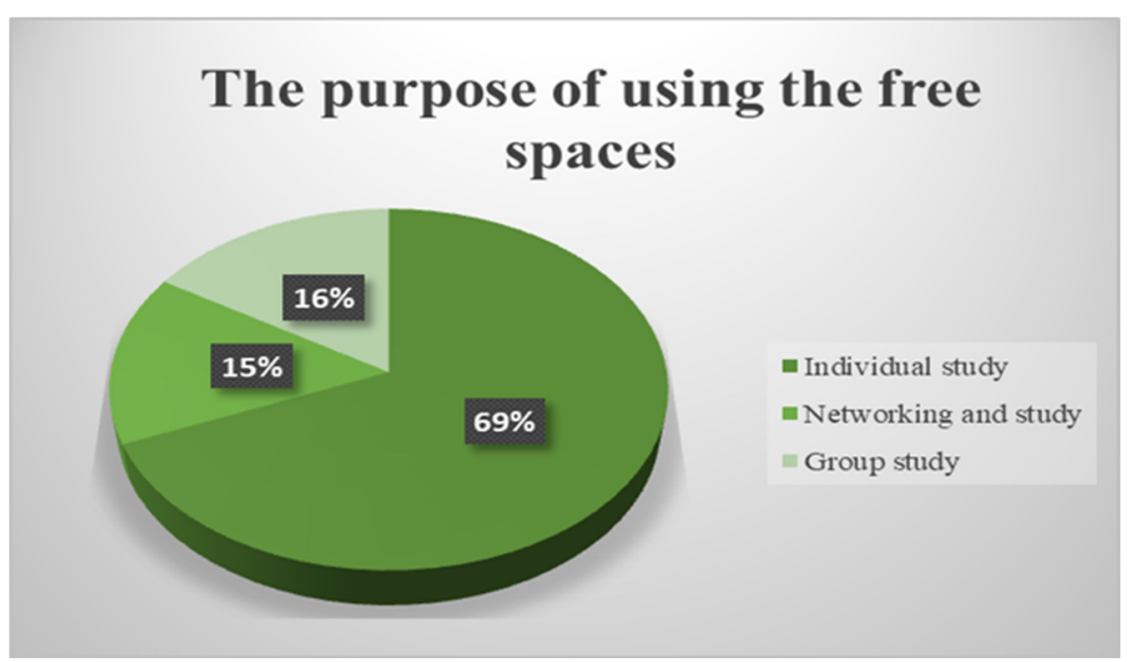

Figure 2. The objectives of the users of the free reading spaces

The first question allowed multiple answers. Therefore, in the table below, the total of the answers exceeds the sum of the respondents. This is because many users checked only one, two or all the answer options, which is reasonable, since the individual study does not severely exclude socialization, and socialization and study and group study are very close in meaning. All respondents answered this question, and 162 stated that they preferred individual study in the free spaces. From our observations, those who checked group study were under 22 years old. The pensioners advocated mainly for socialization and study.

Table 3. The objectives of the users of the free space in numerical avoidance

\begin{tabular}{|l|c|}
\hline Objectives & No. of answers \\
\hline Individual study & 162 \\
\hline Socializing and study & 36 \\
\hline Group study & 38 \\
\hline
\end{tabular}

"Appreciate with a rating from 1 to 5 temperature, lighting, furniture, noise level and Internet connection" was the second challenge in the questionnaire. We considered that the appreciation of these ergonomic elements by marks would express easily the ratings corresponding to the environmental conditions: very bad, bad, acceptable, good and very good conditions. From the collected data, however, we found that not all users had understood this, some scoring with 1 , for example, a low level of noise, as a sign of appreciation of silence, and not as a mark of dissatisfaction ( 3 subjects). Others gave a high score, 5 , to the noise level, complaining alongside or, in the section dedicated to their opinions, "Mention what you would change / improve in the free reading spaces...", they specified that they had been affected by too much noise, not that they had been fine with it. ( 5 persons). At this point, the formulation in our questionnaire was not clear, so the $27 \%$ percentage denouncing very bad noise conditions might not be precise, as well as the $17 \%$, representing positive appraisals, cannot be accurate, due to the deficient expression in the form. We are exclusively responsible for this ambiguity.

From the research based on our direct observation and the numerous suggestions written in the section "Mention what you would change / improve in the free reading spaces" we find that users do not seem to assume that this public space of the National Library is an open one, in which patrons are allowed with personal manifestation, vis-à-vis reading, they are allowed to socialize, which means "to talk", "to communicate". There is an obvious higher sound environment, compared to the reading room, where the use of mobile phones in silent mode is a condition provided by the Regulation. Also, the level of tolerance towards public or private events, which the NLR carries out in the vicinity of these spaces, is very low among those who prefer to occupy the areas for individual study. Several users complained about it in the questionnaire and some others denounced it on the Facebook account of the library. Each time the institution announces by 
The National Library of Romania in the Service of Communities: a Qualitative Analysis to Identify the Needs of the Users in the Free Reading Spaces

social media the schedule for all the events taking place close to these spaces and which might create discomfort.

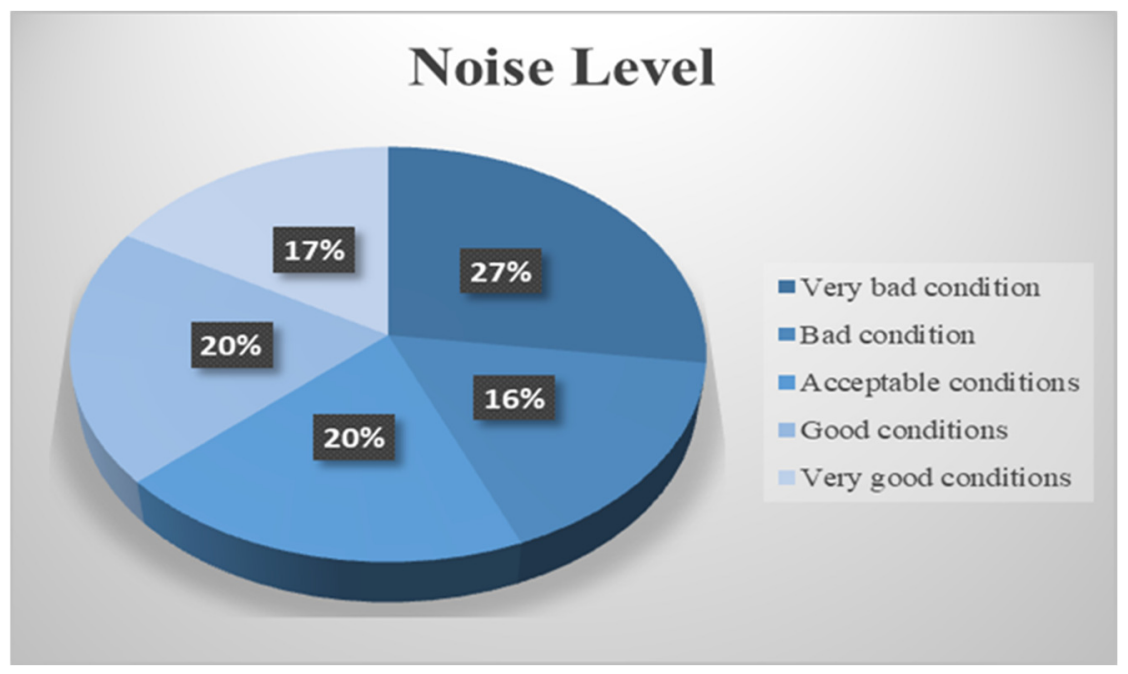

Figure 3. Level of appreciation of noise conditions

Table 4. Number of noise level assessments

\begin{tabular}{|l|c|c|}
\hline Mark 1 (very bad conditions) & 54 & $27 \%$ \\
\hline Mark 2 (bad conditions) & 33 & $17 \%$ \\
\hline Mark 3 (acceptable conditions) & 39 & $20 \%$ \\
\hline Mark 4 (good conditions) & 40 & $20 \%$ \\
\hline Mark 5 (very good conditions) & 33 & $17 \%$ \\
\hline
\end{tabular}

As for the temperature, not a few are those who gave a high score to this element, $28 \%$ of the respondents. Some users have made clear that their appreciation refers to the summer conditions, accusing with many exclamation marks the cold during the winter. According to our direct observations, we already know that a qualitative research of the needs of the users of free space during the winter, at the National Library of Romania, would not be possible. Because of the low temperatures, the patrons prefer to seat in the reading rooms. Still, the free spaces are full by the end of January, before the exam-sessions.

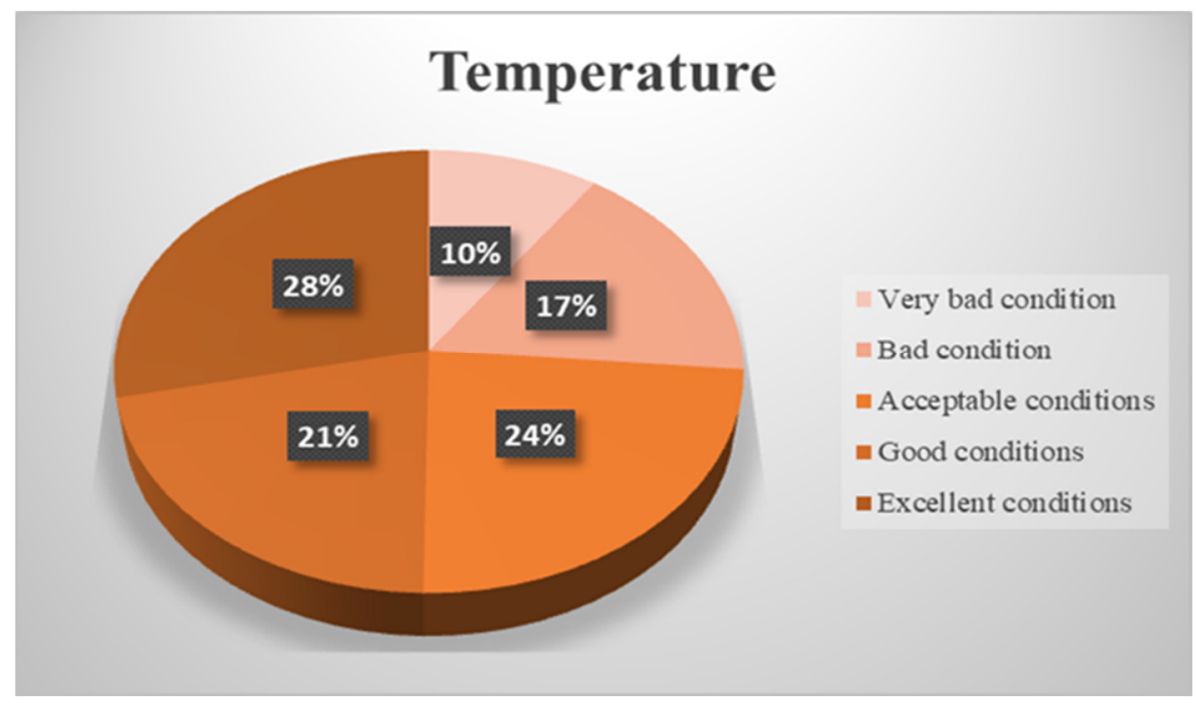

Figure 4. The level of appreciation of the temperature conditions in the open spaces

The quire's data show that $24 \%$ of the total respondents consider the summer temperature conditions as acceptable. 19\% think that the temperature in the NLR is unbearable. We do not intend here to elucidate the administrative, bureaucratic and financial issues, but we can point out 
The National Library of Romania in the Service of Communities:

a real problem, because in winter the free reading spaces remain almost empty.

The lighting and furniture registered clearer favorable results, with positive appreciations, recorded at the 5th issue of the questionnaire, regarding the fact that sometimes not all the table lamps work properly. However, 92 respondents rated the lighting system at highest level.

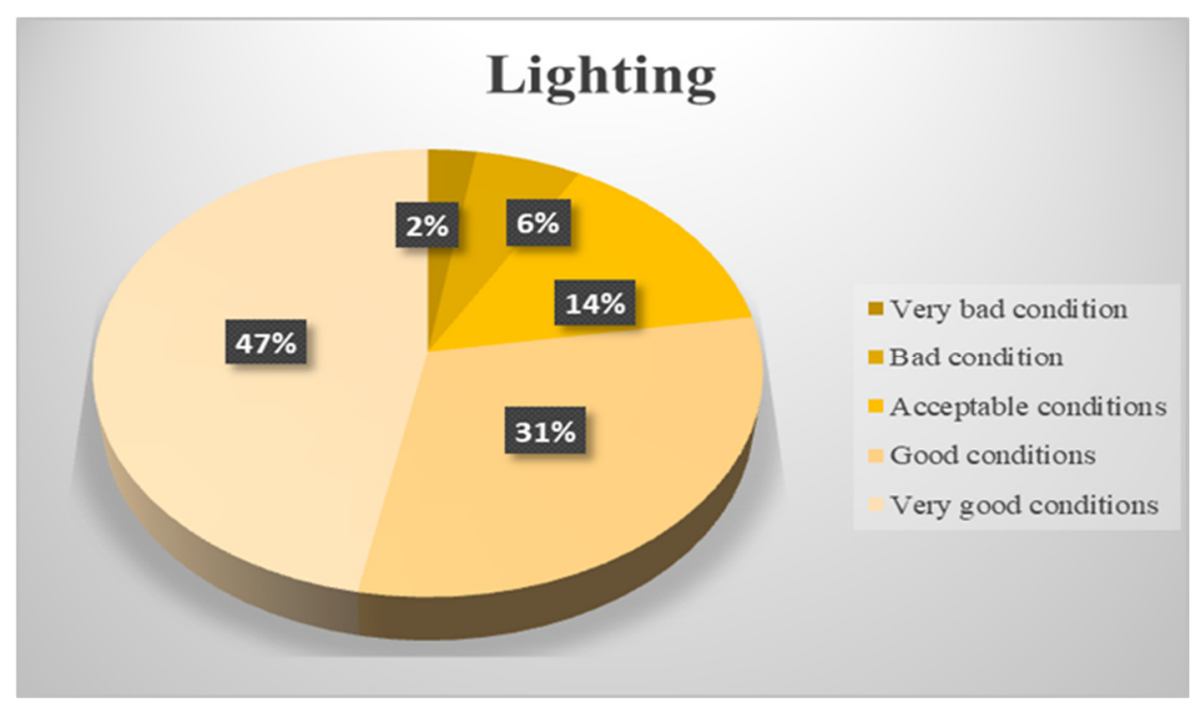

Figure 5. The level of appreciation of lighting in free spaces

Least satisfied with the system were those who complained about the lack of natural light in the areas Alpha, Beta, Gamma, Epsilon and Delta, initially designed for socializing and networking.

Table 5. The level of appreciation for the lighting system in open spaces

\begin{tabular}{|l|c|c|}
\hline Mark 1 (Very bad conditions) & 5 & $3 \%$ \\
\hline Mark 2 (Bad conditions) & 11 & $6 \%$ \\
\hline Mark 3 (Acceptable conditions) & 28 & $14 \%$ \\
\hline Mark 4 (Good conditions) & 60 & $31 \%$ \\
\hline Mark 5 (Very good conditions) & 92 & $47 \%$ \\
\hline
\end{tabular}

The furniture is rated with the maximum mark, 5 , by $49 \%$ of the respondents and only $2 \%$, that is 3 subjects out of the 203, who considered that it deserved the lowest mark, 1. Some of those who have given lower marks to the furniture have motivated their answer at point 5 of the questionnaire, some of them saying that the armchairs are too short for tall persons. However, we noticed that the users often occupied seats for individual study in the spaces designed for socialization, which were furnished with smaller tables. The armchairs do not have the height necessary to fit comfortably onto a study position. The initial design of these particular socializing spaces drew exactly their intended purpose of a relaxed, comfortable communication area, not of a lecture activity. They have no table lamps, and some of them do not benefit of the natural light, remaining totally dependent on the artificial, ambient light. The best part is that, in their vicinity, are sockets, so most readers can use laptops whose screen lights are helpful.

The Internet connection is free of charge and it's provided wirelessly in the free reading spaces. Unfortunately, the simultaneous connection of several users makes the signal weak due to the limited processing capacity of the routers. However, the results of our analysis reveal that, at this point, the differences between satisfied people and the dissatisfied are quite small, most of them deciding that the Internet connectivity is acceptable. 


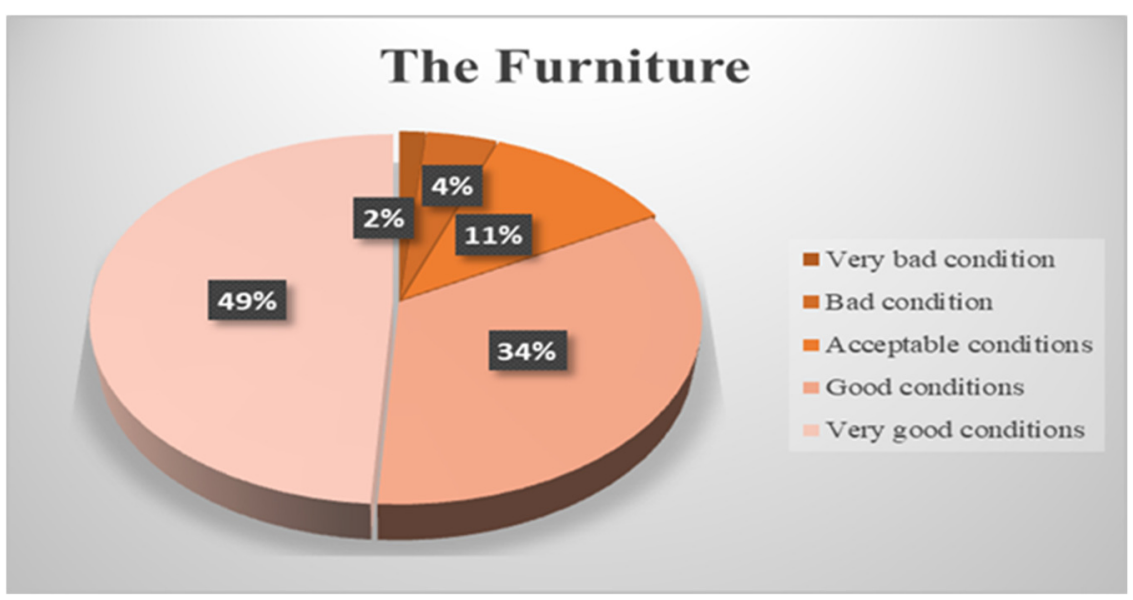

Figure 6. The level of appreciation for the conditions created by the furniture, expressed as a percentage

Table 6. The level of appreciation for the conditions created by the furniture

\begin{tabular}{|l|c|c|}
\hline Mark 1 (Very bad conditions) & 3 & $2 \%$ \\
\hline Mark 2 (Bad conditions) & 8 & $4 \%$ \\
\hline Mark 3 (Acceptable conditions) & 22 & $11 \%$ \\
\hline Mark 4 (Good conditions) & 66 & $34 \%$ \\
\hline Mark 5 (Very good conditions) & 95 & $49 \%$ \\
\hline
\end{tabular}

A problem that none of our respondents left unmarked is the one related to the program. The question "Do you consider that the program in free spaces must: be extended by a few hours daily// extended to Sunday// extended overnight// it may remain so", allowed multiple answers. Most of the users believe that the access schedule should be extended to Sunday. It is worth noticing that those who believed that the program could remain the way it was were not students or professionals involved in an education process. The latter's answers were repeatedly: extended daily, extended to Sunday, and extended overnight.

The library management was very perceptive about these suggestions and decided immediately to extend the program to Saturdays and Sundays during the exam session's periods.

Because the NLR has faced a severe lack of human resources in the last years, especially in the protection and guarding services, it needed great efforts to ensure the key security posts of the institution. Our study reveals that the library did not confront in these free spaces serious misconduct gestures or any other kind of regrettable events. Most of the respondents appreciate the level of civility as high and very high $(51 \%)$, as shown in the data set.

The indicator system, the access and the level of civility obtained the highest marks. Only $8 \%$ of the users consider that the signs are not helpful in the orientation and it is true that, at a first visit, the headquarters of the National Library can be quite complicated in the absence of a proper guidance.

123 people think that the free access is very good, which tells us that most of the users are happy to spend time here, regardless of the use of stairs, elevators or access ramps for people with special needs. Among those who rated accessibility 3 and 4, some suggested the library has to ensure the operation of both elevators in the Atrium, an only one being insufficient in the rush periods.

We consider that point 5 of the questionnaire, "Mention what / how you would change in the free spaces of the National Library of Romania" gave our respondents the opportunity for the most interesting suggestions. Only 6 people said they would not change anything. All the others had useful recommendations. We grouped their opinions, according to the frequency of a same issue: 
The National Library of Romania in the Service of Communities:

a Qualitative Analysis to Identify the Needs of the Users in the Free Reading Spaces

- the high level of noise, which, according to some users, is due to the events that take place on the ground floor (36 respondents). Others (18 respondents) criticize the library staff for disturbing their peace of mind: they wear heels, they talk loudly on the phone, the cleaning staff screams, they organize events that they do not announce;

- insufficient desk sets: 40 users suggest that the library buy a larger number of desk sets, tables and chairs in areas with natural light. Some of them consider that the library does not manage the free spaces judiciously;

- inappropriate furniture: 19 of our respondents propose us to adjust the furniture by equipping them with higher chairs, to allow a correct, healthy position for the study and 17 have noticed that not all the sockets and lamps always work;

- cleanliness is claimed by 16 users. They consider that the tables and the restrooms are not always disinfected properly;

- Where are the books? 13 people wonder why they do not have access to the books in these free spaces and 7 users suggest that in the National Library of Romania the environment would be warmer if we organize some book shelves and if we decorate the places with some indoor plants.

The last issue, the 6th in the questionnaire - "Do you think that a public library can create a state of happiness? (Check the answer you consider correct!)" - gave the possibility of a single answer (Yes or No). 174 people answered positively and only 12 consider that the library cannot be a creator of happiness. Few of the optimistic users suggested that if it was not about happiness in the library, it was is sure about mind comfort, education, personal thinking, free speech.

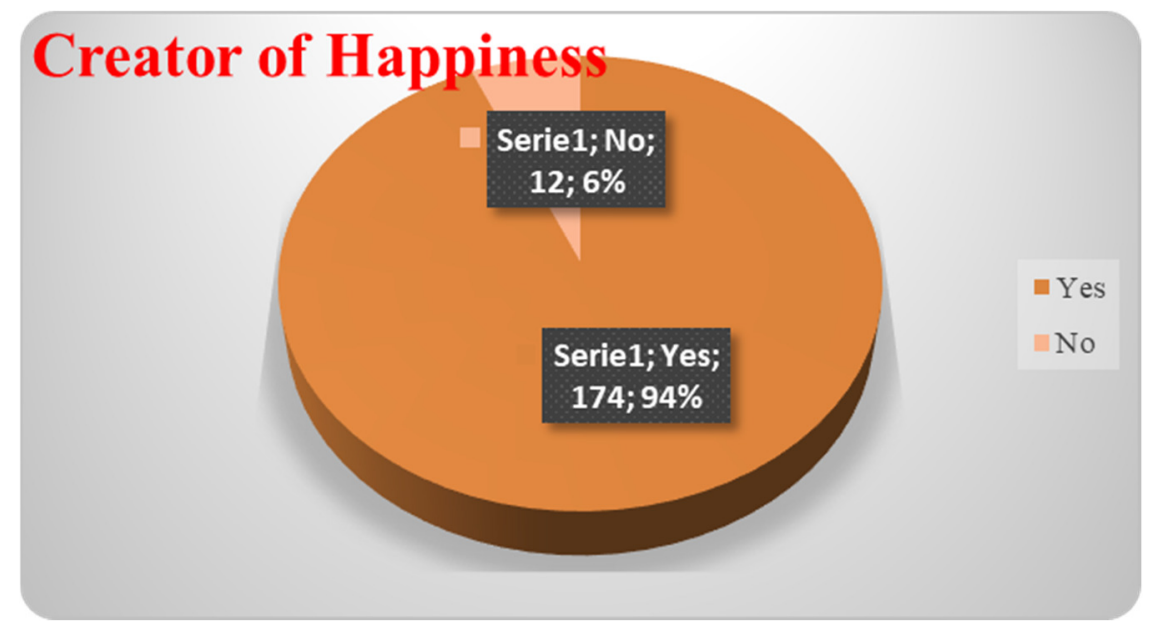

Figure 7. The user's opinions about the library's ability to create happiness

\subsection{Discussion}

We consider that the research has reached its objectives. The study let us know where these people are coming from in such a large number, looking for a seat, early in the morning - most of them in the free spaces of the National Library of Romania. A large majority comes from the Bucharest university environment. This is a great opportunity for the NLR, it offers perspectives but also creates demands. First of all, it calls for a strategic recalibration of the library public services and a closer cooperation with the Ministry of Culture in achieving the budget, in order to provide these young people with fundamental study conditions: normal temperature, comfortable spaces, lights, furniture, office accessories and hygiene.

We understand now why these people are coming to the NLR: they need space for individual study, mainly. Secondary, they need socialization and third, they are looking for the opportunity to study in their groups. They require networking, communication, information access, they want peace. The library will also have to deal with the noise problem. As its financial needs are important issues to deal with, the Management team has to balance the timing for the private events held in the proximity of these public reading spaces, so that the users would not be disturbed. 
The National Library of Romania in the Service of Communities: a Qualitative Analysis to Identify the Needs of the Users in the Free Reading Spaces

The option of individual study outside the collections can be frustrating for the library, but the choice comes naturally in the context in which the NLR has not yet designed specialized offers for these spaces (new entries in our collections, video stations, free access to some book shelves (organized from the general fund of the library), touristic or social assistance info point, Romanian as a foreign language courses, etc.). The lack of such personalized services for these areas determines a mandatory observation: as far as the free reading spaces are concerned, the library becomes a passive assistant at the educational process of its users, as they seem to be less interested in our documentary resources.

We understand that library staff should be more careful when going through these spaces, so that the users wouldn't be disturbed. A special regulation for these areas might be useful, in order to assure procedures for librarians as well as for the readers.

The study reveals that they would like books, music and plants in these spaces. In fact, they want a friendly, stimulating, learning conducive environment.

The research also reveals a paradox. Though many users complain about all kinds of issues, 176 persons out of 203 can think of happiness in the library. It seems that this feeling it is not conditioned by certain technical investments. It demands us the responsibility to receive these people with warmth, to honor them, to help them.

An important aspect of our analysis consists in the further questions raised by its results, future issues of library's concern: How can we keep these students as our users after they finish schools? Are we able to make them interested on the library's collections as well? Can we offer them more than a passive assistance in their education? Can we do something consistent for their personal development? What special services we can create and proceed for the users of these areas in the NLR?

\section{Conclusions}

It turns out that the social tasks of the National Library of Romania become more important and more consistent every day, especially when we refer to certain groups of our communities: pupils, students, people working in the educational environment, professionals of liberal fields, retired persons. Users of different nationalities, belonging to various social and professional categories come to the library to find a peaceful place to study, a pleasant environment, and opportunity to communicate and to meet each other. Despite the inconveniences they complain about without any restraint, the patrons admit that a public library is the place to look for when they need information, even if they use their own tools to get it. Still, a daily observation of their activity would reveal that a large majority does not seem to realize the importance of guidance through the Internet resources, since just a few users ask a librarian in the Front Office for help finding certain information, unless they access the reading room service.

However, the NLR lives today a certain sense of freedom, which is given by those who come to its spaces. Paradoxically, when the budgets are austere, as in most cultural institutions in the country, The National Library is experiencing a moment of grace: it has become one of the few places in Romania, where the societal discourse does not seem fragmented by deep, poisoned wounds, where people sit next to each other, without the fear of the different opinions, where everyone comes, knowing that a free corner is always to be found, a chair and a bit of warm light.

It looks more like a social shelter for some people. Actually, there are days and evenings when the guardians confront users who don't want to leave the building at the closing hours. The library has to manage often such situations. In order to be able to handle such cases, the National Library of Romania must cooperate closely with institutions with responsibilities in the field of social protection.

For others, the NLR has become a cultural shelter. They are those who come in the free spaces for reading their own books. Their increasing number in these spaces, with 12,500 people in a single year, is not a common phenomenon. It might look like something more powerful than gathering 
The National Library of Romania in the Service of Communities: a Qualitative Analysis to Identify the Needs of the Users in the Free Reading Spaces

people around the study. The idea of common free reading seems to be more than just being in the need of space. What if we need each other in a higher sense than we already know? The anthropologist Michele Petit, at the opening of a conference of the Association of Librarians in France, in 2014, said about libraries and books that they "... were always welcome for exiles. Many of us have used and have abused of the hospitality of reading, of its huge character of a mother. Reading is a way to resist exclusion, oppression. To read is a way of recovering the subject position instead of the derogatory object of the discourse of others..." (Gibouin 2016) [2]. The anthropologist's words lead us to a natural question today. Should the information boom be a form of aggression, in front of which the individual feels the need of a shelter?! We would never understand better the library's vocation nowadays.

To find out with more accuracy what the public needs from free spaces, the library need the results of a wider and rigorous professional study, an interdisciplinary one, a project that should involve sociologists, teachers, anthropologists, historians, IT people and, of course, some librarians who understand their role and the epoch they live in. With such a research, The National Library could co-interest the Government in developing a strategy to support culture through education, by promoting reading, by bringing users closer to the largest collection of documents in Romania. The library can become a valuable binder in a permanent, constructive social dialogue. Such qualitative studies must be carried out periodically, in order to understand the reading habits of the communities, their development needs, in conjunction with the changes imposed by the information society and with the needs of the labor market. They are essential elements in the elaboration of cultural strategic policies in a European state.

The acquisition of an RFID system and the setting up of some book shelves from the general fund of documents in the free reading spaces should not be the most difficult of the historical tests of the National Library and of the Romanian State. It would connect people directly to the general fund, it would give them the opportunity to communicate in all the affordable dimensions in the knowledge society. The advantages of the library would be enormous, in terms of obtaining specific data regarding the number of users, the time spent in the library, the types of the information resources requested. Today, the library can only technically monitor the documents requested in the reading rooms and the activity of its few employees.

Library literature today develops topics of interest in the information society, with practical applications particularly important for users with concerns in the area of scientific research. The valuable works, elaborated by the National Bibliography Department, are important for the users who need an exhaustive, up-to-date information on the documentary resources available in Romania. The book Ghidul de identificare a publicațiilor pseudoștiințifice [Guide for identifying predatory publications] (Constantinescu 2018) can prove to be a very useful tool, both for librarians and users interested in a rigorous selection of information resources. Such works, as well as the guidance services offered by specialist librarians in bibliographic references are essential elements in the relationship that the library can build with its users, coming in a large majority from the university environment.

In fact, the NLR must redefine its mission, in accordance with the new milestones of the information society and it has to be in a continuous social dialogue, if it intends to maintain its central place in our culture. In their turn, the authorities must know that investments in libraries return efficiently in a society where the individual is aware, responsible and educated. As for the governmental investment in the National Library of Romania, this would be a legitimate priority in a national strategy, elaborated in the interest of our culture, as a strengthening part of a coherent Europe. 
The National Library of Romania in the Service of Communities: a Qualitative Analysis to Identify the Needs of the Users in the Free Reading Spaces

\section{Notes}

1. Table 1 is extracted from an internal material issued by the Institutional Development Service of the National Library of Romania in 2018.

2. Original version (French): "Les livres ont toujours été accueillants aux exilés. Nous sommes nombreux à avoir usé et abusé de l'hospitalité de la lecture, de son caractère englobant, maternant. Lire est un moyen de résister à l'exclusion, à l'oppression. Lire est un moyen de reconquérir une position de sujet au lieu d'être l'objet moqué du discours des autres".

\section{References}

Biblioteca Națională a României (2018a) Raport anual de activitate [Annual Activity Report] [online], available: http:/www.bibnat.ro/dyn-doc/Raport anual_BNR_2018.pdf [accessed 3 June 2019].

Biblioteca Națională a României (2018b) Regulamentul de acces al utilizatorilor la colecțiile curente și la serviciile Bibliotecii Naționale a României [Regulation for users `access to current collections and to the services of the National Library of Romania] [online], available: http:// bit.ly/rrbsi342019m [accessed 1 June 2019].

Biblioteca Națională a României (s.a.) Ghidul bibliotecii [The Library Guide] [online], available: http://www.bibnat.ro/Ghidul-bibliotecii-s8-ro.htm [accessed 3 June 2019].

Cicovschi, A. (2018) Românii se întorc la lectură. Piața de carte atinge maximul ultimilor 7 ani [Romanians return to reading. The book market reaches the maximum of the last 7 years], in Adevărul [online], 11 iunie 2018, available: http://bit.ly/rrbsi342019i [accessed 25 May 2019].

Constantinescu, M. (2018) Ghid de identificare a publicațiilor pseudoştiinţifice [Guide for identifying predatory publications] [online], available: http://bit.ly/ghidpseudo [accessed 6 November 2018].

Gibouin, S. (2016) La Bibliothèque: le lieu des liens [The Library: the place of connections] [online], available: http://bit.ly/rrbsi342019j [accessed 25 May 2019].

Institutul Național de Statistică (2017) Activitatea unităților cultural artistice [The activity of cultural and artistic institutions] [online], available: http://bit.ly/rrbsi342019k [accessed 25 May 2019].

Peticilă, M. (2018) Care este procentul de analfabetism funcțional în România? [Which is the percentage of functional illiteracy in Romania?] [online], available: http://bit.ly/rrbsi3420191 [accessed 25 May 2019]. 